Hemophilia associations should be recommended for educational programs for patients and caregivers. Hematologists and nongovernmental organizations can work together for lifelong educational programs. Finally, we recommend holding patient workshops twice a year as well as publishing simple books or brochures in each local language to improve the knowledge and therefore the quality of life of these patients.

Keywords: Knowledge, Hemophilia, Treatment, Disease

Anahtar Sözcükler: Bilgi, Hemofili, Tedavi, Hastalık

\section{Ethics}

Ethics Committee Approval: This study was approved by the Ethics Committee of Shiraz University of Medical Sciences.

\section{Authorship Contributions}

Concept: Mehran Karimi; Design: Mehran Karimi; Editing the Manuscript: Mehran Karimi; Data Collection or Processing: Zohreh Zahedi; Analysis or Interpretation: Sezaneh Haghpanah; Literature Search: Tahereh Zarei; Writing: Tahereh Zarei.

Conflict of Interest: The authors of this paper have no conflicts of interest, including specific financial interests, relationships, and/or affiliations relevant to the subject matter or materials included.

\section{References}

1. Stachnik J. Hemophilia: etiology, complications, and current options in management. Formulary 2010;45:218.

2. Lee CA, Berntorp EE, Hoots WK. Textbook of Hemophilia. New York, John Wiley \& Sons, 2011.

3. White GC 2nd, Rosendaal F, Aledort LM, Lusher JM, Rothschild C, Ingerslev J; Factor VIII and Factor IX Subcommittee. Definitions in hemophilia. Recommendation of the Scientific Subcommittee on Factor VIII and Factor IX of the Scientific and Standardization Committee of the International Society on Thrombosis and Haemostasis. Thromb Haemost $2001 ; 85: 560$.

4. Smith PS, Levine PH. The benefits of comprehensive care of hemophilia: a five-year study of outcomes. Am J Public Health 1984;74:616-617.

5. Soucie JM, Nuss R, Evatt B, Abdelhak A, Cowan L, Hill H, Kolakoski M, Wilber N. Mortality among males with hemophilia: relations with source of medical care. Blood 2000;96:437-442.

6. Teitel J, Barnard D, Israels S, Lillicrap D, Poon MC, Sek J. Home management of haemophilia. Haemophilia 2004;10:118-133.

7. Lindvall K, Colstrup L, Wollter IM, Klemenz G, Loogna K, Grönhaug S, Thykjaer $\mathrm{H}$. Compliance with treatment and understanding of own disease in patients with severe and moderate haemophilia. Haemophilia 2006;12:4751.

8. Nazzaro AM, Owens S, Hoots WK, Larson KL. Knowledge, attitudes, and behaviors of youths in the US hemophilia population: results of a national survey. Am J Public Health 2006;96:1618-1622.

9. Miller K, Guelcher C, Taylor A. Haemophilia A: patients' knowledge level of treatment and sources of treatment-related information. Haemophilia 2009;15:73-77.

\title{
Therapeutic Plasma Exchange Ameliorates Incompatible Crossmatches
}

\section{Çapraz Karşılaşıırma Uyumsuzluklarını Ortadan Kaldıran Tedavi Edici Plazma Değiş̧imi}

\author{
Mehmet Özen¹, Sinan Erkul2, Gülen Sezer Alptekin Erkul2, Özlem Genç3, Engin Akgül2, Ahmet Hakan Vural2 \\ ${ }_{1}^{1}$ Dumlupınar University Faculty of Medicine, Department of Hematology, Kütahya, Turkey \\ 2Dumlupınar University Faculty of Medicine, Department of Cardiac Surgery, Kütahya, Turkey \\ ${ }^{3}$ Dumlupınar University Faculty of Medicine, Blood Bank Unit, Kütahya, Turkey
}

\section{To the Editor,}

Red blood cell (RBC) transfusion is a risk factor for mortality and morbidity in coronary artery bypass graft (CABG) surgery, and transfusion-related adverse effects may be catastrophic in these patients $[1,2,3,4]$. Unfortunately, there are no recommendations for these patients regarding how to proceed in the case of incompatible crossmatch tests against donors' blood. To our knowledge, there is no report about the role of therapeutic plasma exchange (TPE) in resolving incompatible crossmatches.

A 73-year-old man was admitted to our hospital because of chest pain. He had no previous medical history of coronary artery disease or any other diseases, including hemolytic disease and recent infection. In addition, he used no medication and had not received blood transfusions. After coronary angiography, a 
CABG was planned for the patient. Because of critical coronary artery lesions, he had to undergo the operation as soon as possible. His laboratory tests revealed mild normocytic anemia with hemoglobin of $12.8 \mathrm{~g} / \mathrm{dL}$, mean corpuscular volume of $82.2 \mathrm{fL}$, white blood cell count of $9200 / \mu \mathrm{L}$, and platelet count of $281,000 / \mu \mathrm{L}$. His biochemical results were normal for renal and liver function tests. The patient's blood group was B Rh D positive based on forward and reverse grouping. Whole blood transfusion was planned for the CABG procedure by the surgeons as a part of their conventional approach. However, cross match results revealed $3+$ reactions against $B$ Rh $D$ positive donors' whole blood and other B Rh D positive RBCs in the blood bank (Figure $1 A$ ). Direct Coombs test results were $2+A H G$ and IgG (Figure $1 B)$. Due to the urgency of the planned $C A B G$, we did not wait for detailed antibody screening test results, and TPE (Infomed, Geneva, Switzerland) was performed. Total body plasma was exchanged with fresh frozen plasma within $2 \mathrm{~h}$. After one TPE procedure, the cross-reaction to donors' whole blood was $2+$. TPE was performed again 1 day later, and after the second TPE, the crossmatches were compatible (Figures 1C and 1D). There was no adverse effect due to TPE. We operated after the second TPE, used a regular erythrocyte suspension and whole blood, administered $40 \mathrm{mg} /$ day intravenous methylprednisolone for 4 days, and discharged the patient 1 week after the operation. Two weeks after the operation, he had no hematological or antibody-related disease and he had a normal complete blood count with compatible crossmatches. He also had no antibodies related to incompatible crossmatches.

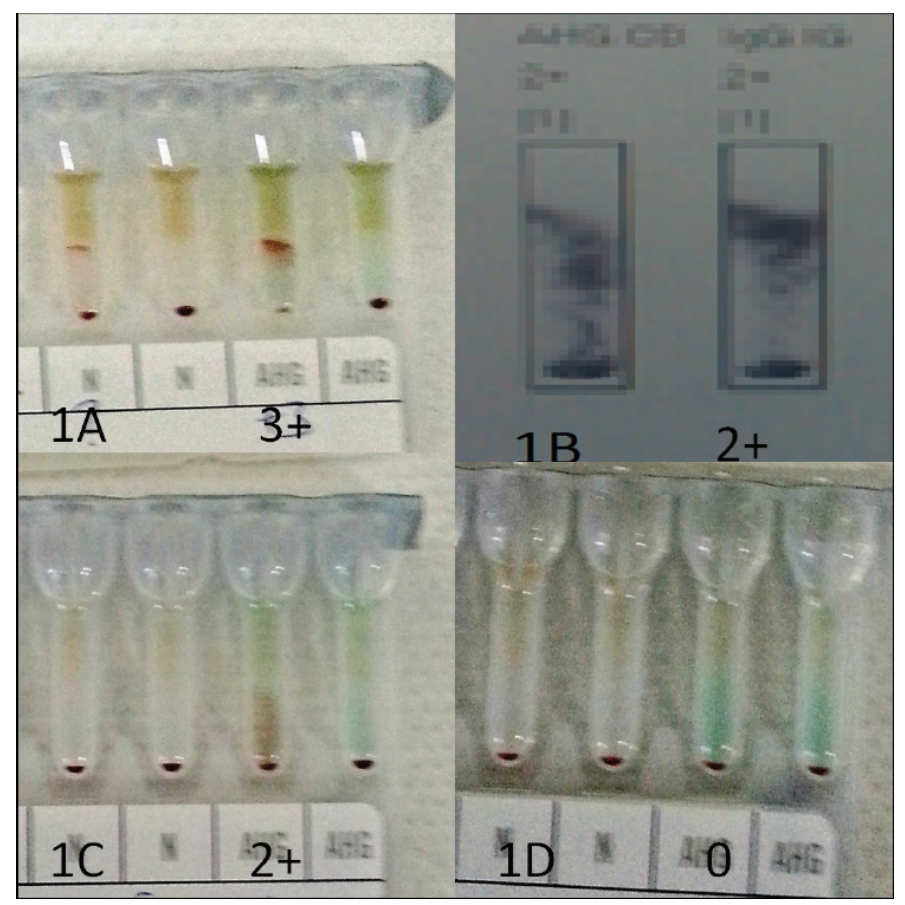

Figure 1. A) Crossmatch before therapeutic plasma exchange (TPE), B) direct Coombs test before TPE, C) crossmatch after one TPE, D) crossmatch after two TPEs. All tests were performed with DG gel cards (Grifols) and used the Wadiana automated blood bank (Grifols, SantCugat del Valles, Barcelona, Spain).
In a patient undergoing $\mathrm{CABG}$, an incompatible blood transfusion can lead to perioperative hemolysis and increased mortality $[5,6]$. Defining the antibodies and finding compatible blood for a patient with incompatible crossmatches can be a challenging and time-consuming problem $[5,7]$.

TPE is an important treatment modality for many autoimmune conditions and helps by removing autoantibodies [8]. Our patient did not have time to wait and needed CABG urgently. Therefore, we assumed that the patient had antibody-related autoimmune hemolytic anemia and treated him with TPE. We report that this approach may be efficient for patients with incompatible crossmatch results even if they do not have autoimmune hemolytic anemia. Therefore, TPE might be reserved for urgent conditions or when identification of antibodies is inconclusive.

Keywords: Cardiac surgery, Apheresis, Crossmatch, Transfusion medicine

Anahtar Sözcükler: Kalp cerrahisi, Aferez, Çapraz karşılaştırma, Transfüzyon tıbbı

\section{Authorship Contributions}

Concept: Mehmet Özen, Sinan Erkul; Design: Mehmet Özen, Ahmet Hakan Vural; Data Collection or Processing: Özlem Genç, Sinan Erkul, Gülen Sezer Alptekin Erkul, Engin Akgül; Analysis or Interpretation: Mehmet Özen, Ahmet Hakan Vural; Writing: Mehmet Özen.

Conflict of Interest: The authors of this paper have no conflicts of interest, including specific financial interests, relationships, and/or affiliations relevant to the subject matter or materials included.

\section{References}

1. Evanovitch D. A primer in pretransfusion testing. Transfus Apher Sci 2012;46:281-286.

2. Santos $A A$, Silva JP, Silva Lda $F$, Sousa $A G$, Piotto RF, Baumgratz JF. Therapeutic options to minimize allogeneic blood transfusions and their adverse effects in cardiac surgery: a systematic review. Rev Bras Cir Cardiovasc 2014;29:606-621.

3. Senay $\mathrm{S}$, Toraman $\mathrm{F}$, Karabulut $\mathrm{H}$, Alhan $\mathrm{C}$. Is it the patient or the physician who cannot tolerate anemia? A prospective analysis in 1854 non-transfused coronary artery surgery patients. Perfusion 2009;24:373-380.

4. Society of Thoracic Surgeons Blood Conservation Guideline Task Force, Ferraris VA, Ferraris SP, Saha SP, Hessel EA 2nd, Haan CK, Royston BD, Bridges CR, Higgins RS, Despotis G, Brown JR; Society of Cardiovascular Anesthesiologists Special Task Force on Blood Transfusion, Spiess BD, ShoreLesserson L, Stafford-Smith M, Mazer CD, Bennett-Guerrero E, Hill SE, Body S. Perioperative blood transfusion and blood conservation in cardiac surgery: the Society of Thoracic Surgeons and the Society of Cardiovascular Anesthesiologists clinical practice guidelines. Ann Thorac Surg 2007;83(5 Suppl):27-86. 
5. White MJ, Hazard SW 3rd, Frank SM, Boyd JS, Wick EC, Ness PM, Tobian AA. The evolution of perioperative transfusion testing and blood ordering. Anesth Analg 2015;120:1196-1203.

6. Rakic S, Belic B, Erceg S, Jovanovic R, Kulic Z, Stefanovic N, Belic A, Uzurov V, Spasojevic J. Complications in the use of blood transfusions-alloimmunization in polytransfused patients. Med Pregl 1999;52:375378.
7. Sanz C, Nomdedeu M, Belkaid M, Martinez I, Nomdedeu B, Pereira A. Red blood cell alloimmunization in transfused patients with myelodysplastic syndrome or chronic myelomonocytic leukemia. Transfusion 2013;53:710-715.

8. Sengul Samanci N, Ayer M, Gursu M, Ar MC, Yel K, Ergen A, Dogan EE, Karadag S, Cebeci E, Toptas M, Kazancioglu R, Ozturk S. Patients treated with therapeutic plasma exchange: a single center experience. Transfus Apher Sci 2014;51:83-89.

\title{
Megaloblastic Anemia with Ring Sideroblasts is not Always Myelodysplastic Syndrome
}

\section{Halka Sideroblastı Megaloblastik Anemi Her Zaman Miyelodisplastik Sendrom Olmayabilir}

\author{
Neha Chopra Narang1, Mrinalini Kotru², Kavana Rao1, Meera Sikka1 \\ 1 University College of Medical Sciences, Department of Pathology, Delhi, India \\ 2 University College of Medical Sciences, Department of Hematopathology, Delhi, India
}

\section{To the Editor,}

Ring sideroblasts are morphological hallmarks of hereditary and acquired sideroblastic anemias [1]. The International Working Group on Morphology of Myelodysplastic syndrome (MDS) defined ring sideroblasts as erythroblasts in which a minimum of five siderotic granules cover at least one-third of the circumference of the nucleus.

We present the case of an 18-year-old female who had lowgrade fever, jaundice, nausea, vomiting, and shortness of breath for 25 days. The patient was not an alcoholic and not on any drugs. On examination she appeared pale and icteric; however, no hepatosplenomegaly was noted. A complete blood count $(\mathrm{CBC})$ and bone marrow examination were performed. The CBC revealed $\mathrm{Hb}: 75 \mathrm{~g} / \mathrm{L}, \mathrm{PCV}: 0.232 \%, \mathrm{RBC}: 2.15 \times 10^{12} / \mathrm{L}$, MCV: $108 \mathrm{fL}, \mathrm{MCH}: 34.8 \mathrm{pg}, \mathrm{MCHC}: 32.2 \mathrm{~g} / \mathrm{dL}$, total leukocyte count: $2.6 \times 109 / \mathrm{L}$, platelet count: $87 \times 10^{9} / \mathrm{L}$, reticulocyte count: $0.8 \%$, and differential leukocyte count: N74 L26. A peripheral smear revealed pancytopenia with dimorphic anemia. No coarse basophilic stippling was noted (as seen in lead poisoning). Bone marrow aspirate was particulate and hypercellular for age with erythroid hyperplasia, showing megaloblastic maturation and dyserythropoiesis (Figure 1). Giant myeloid forms were seen. Megakaryocytes appeared adequate and were normal in morphology. Bone marrow iron was increased (grade 3) and showed 6\%-7\% ring sideroblasts (Figure 2). A final diagnosis of megaloblastic anemia with ring sideroblasts was made after excluding various other causes of the same symptoms. The patient was put on a therapeutic trial of hematinics (vitamin B12, folic acid, and pyridoxine) and showed improvement. After therapy, a CBC revealed Hb: $122 \mathrm{~g} / \mathrm{L}$, PCV: $0.432 \%$, RBC: 4.15×1012/L, MCV: $85 \mathrm{fL}, \mathrm{MCH}: 30.8$ pg, MCHC: $31.2 \mathrm{~g} / \mathrm{dL}$, total leukocyte count: 5.6×109/L, and platelet count: $177 \times 109 / \mathrm{L}$. However, a repeat bone marrow examination could not be performed as the patient did not comply.

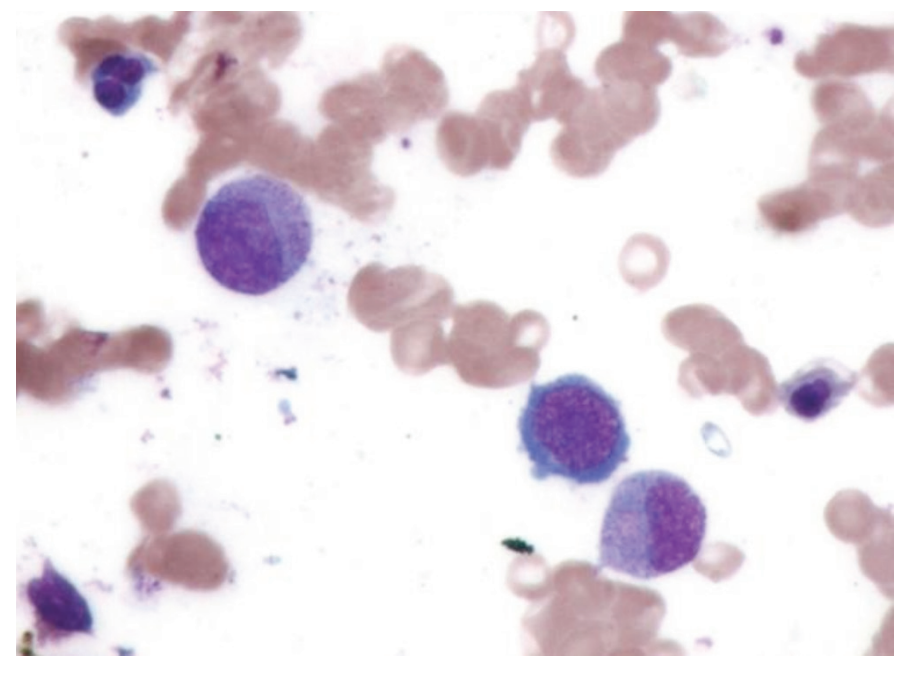

Figure 1. Bone marrow aspiration: megaloblastic maturation with dyserythropoiesis and giant myelocyte (1000x). 